The definitive version is available at http://wileyonlinelibrary.com

http://onlinelibrary.wiley.com/doi/10.1111/ajph.12317/full

\title{
The Politics of National Recognition: Honouring Australians in a Post-Imperial World ${ }^{\mathbf{1}}$
}

\author{
Karen Fox and Samuel Furphy
}

\begin{abstract}
The announcement in January 2015 that Prince Philip had been chosen to receive an Australian knighthood (an honour which itself had been controversially revived the previous year) sparked a fury of debate about honours, and about the continuance of a British connection in Australia's national life. Such debates were not new, echoing earlier arguments about honours as a national or imperial symbol. Through two related case studies - the Australian honours system and the Australian of the Year award - this article explores the politics of national recognition in 1970s and 1980s Australia. We consider both the politics involved in the creation and alteration of awards by which individual achievement and service are recognised by the nation, and the politics involved in imagining and recognising an Australian nation as expressed in those awards. We argue that these two institutions were more than a means to acknowledge hard work or sacrifice; they were also significant sites for contests over the nature of Australia’s post-imperial identity.
\end{abstract}

Like most modern nations, Australia uses an official system of honours to acknowledge and celebrate the services and achievements of its citizens. This formal system is complemented by the more populist Australian of the Year award. In the twenty-first century these two honorific institutions are familiar and - with some notable exceptions - widely valued and accepted elements of the social and symbolic landscape. For a significant period in the 1970s and 1980s, however, both were caught up in complicated struggles over national symbols and identities, occurring as a consequence of Australia's emergence as an independent nation in a post-imperial world. This article explores what we are calling "the politics of national recognition" in 1970s and 1980s Australia, with a focus on two complementary case studies. First, we analyse the shift from the imperial system of honours to the Order of Australia. Second, we describe the troubled early history of the Australian of the Year award. As expressions of civic culture in a transitional period, these two institutions were particularly notable for the contested nature of their development. Our case studies exhibit an ongoing clash in political discourse between an emergent new nationalism and a residual but persistent connection to Britishness, even after the decline of the Empire. The histories of these two institutions reveal commonalities that help to illuminate the nature of the contests over Australian national identity that took place in these years.

There has been an ongoing debate among Australian historians over the relative influence of British race patriotism and radical nationalism in the nation's past. In 2001, Neville Meaney critiqued what he saw as a "teleological" view of nationalism in Australian historical scholarship, which tended "to assume that European Australians have been engaged from early in their history in an inexorable struggle for national independence". ${ }^{2}$ Like other scholars, such as Russell McGregor, he identified a radical nationalist brand of history writing dominant in the second half of the twentieth century. This

\footnotetext{
${ }^{1}$ The authors are grateful to Frank Bongiorno and the anonymous reviewers for their helpful comments on earlier versions of this article.

${ }^{2}$ Neville Meaney, "Britishness and Australian Identity: The Problem of Nationalism in Australian History and Historiography”, Australian Historical Studies Vol. 32, 116 (2001), p.76. See also Neville Meaney, "Britishness and Australia: Some Reflections”, Journal of Imperial and Commonwealth History Vol. 31, 2 (2003), pp.121-135.
} 
school of writing, as McGregor has outlined, "construed British loyalties and identities as impediments to the realisation of true Australian nationhood", assumed "an inherent antipathy between Britishness and Australian nationalism", and looked for the "final rupturing" of links between the two countries. ${ }^{3}$ In contrast, Meaney suggested that "in the nationalist era [i.e. the 1870s to the 1960s] Britishness was the dominant cultural myth in Australia, the dominant social idea giving meaning to "the people"”. ${ }^{4}$ Over and over again, he argued, "the British failed the Australians", pushing them to prefer their own interests over a cultural ideal of unity with British peoples, until eventually forced by events - particularly Britain's turn to Europe - to abandon the dream. ${ }^{5}$

A number of scholars have since followed and advanced Meaney's view of Australia's changing relationship with Britain. ${ }^{6}$ In their book The Unknown Nation: Australia After Empire James Curran and Stuart Ward argued that Australians faced a dilemma in the 1960s and 1970s, as the end of empire necessitated the creation of a new national image. ${ }^{7}$ They posited, for example, that from its beginning the "underlying rationale" of the Australian of the Year Award was "to invest Australia Day with a sense of ritual and tradition". ${ }^{8}$ The award was closely associated with increasing pleas in the 1960s for "a more ritualised observance of Australia Day", which would suit a maturing nation "emerging from Britain's shadow”. The difficulty was not only to decide what forms celebrations might take, but how to engage Australians in the idea of a national holiday. ${ }^{9}$

Curran and Ward also engaged with a wider issue in British imperial historiography that was highlighted by A. G. Hopkins in his 2008 article "Rethinking Decolonization". Hopkins had observed that the "moment of decolonization" in former British colonies was marked by the creation of new national flags, anthems and other symbols, including honours and awards. Crucially, he noted that similar changes took place in the dominions (including Australia) at around the same time, a parallel which had received little attention from historians of decolonisation. ${ }^{10}$ Rather than "mere window dressing", he considered that the adoption of new civic emblems by the former dominions "represented a fundamental and remarkably neglected transformation of the whole of the empireCommonwealth". Such changes in national symbols "marked the end of long-established connections" between Britain and the dominions, and were in some respects more significant shifts than the attainment of formal independence elsewhere, for they "involved the destruction of the core concept of Britishness ... and the creation of new national identities". ${ }^{11}$

Curran and Ward question Hopkins's account of the development of national identities that had been repressed by imperial patriotism; instead, they stress what Ward has elsewhere referred to as "the

\footnotetext{
${ }^{3}$ Russell McGregor, “The Necessity of Britishness: Ethno-Cultural Roots of Australian Nationalism”, Nations and Nationalism Vol. 12, 3 (2006), pp.494-495. Among the scholars and works often identified with this trend have been Manning Clark, 'The Old Dead Tree and the Young Tree Green' vol. VI of A History of Australia (Melbourne, 1987); Stephen Alomes, A Nation at Last? The Changing Character of Australian Nationalism, 1880-1988 (Sydney, 1988); Russel Ward, A Nation For a Continent: The History of Australia, 1901-1975 (Melbourne, 1977); David Day, The Great Betrayal: Britain, Australia and the Onset of the Pacific War, 1939-42 (Sydney, 1988); David Day, Reluctant Nation: Australia and the Allied Defeat of Japan, 1942-45 (Melbourne, 1992).

${ }^{4}$ Meaney, "Britishness and Australian Identity”, p.79.

${ }^{5}$ Ibid., pp.88-89.

${ }^{6}$ For example, Stuart Ward, Australia and the British Embrace: The Demise of the Imperial Ideal (Carlton South, 2001).

${ }^{7}$ James Curran and Stuart Ward, The Unknown Nation: Australia After Empire (Carlton, 2010).

${ }^{8}$ Ibid., p.193.

${ }^{9}$ Ibid., p.194.

${ }^{10}$ A. G. Hopkins, "Rethinking Decolonization”, Past and Present, Vol. 200, 1 (2008), pp.211, 215. David Goldsworthy had earlier lamented the lack of scholarly attention to the connections between decolonisation of the formal empire and the 'de-dominionisation' of Australia. David Goldsworthy, Losing the Blanket: Australia and the End of Britain's Empire (Carlton South, 2002), p.3.

${ }^{11}$ Ibid., p.215.
} 
disoriented identities of the post-imperial world”. ${ }^{12}$ From the mid-1960s, they state, commentators in Australia, Canada and New Zealand began to speak and write about a "new nationalism" - an enthusiastic awakening from the British imperial identity of the past - which was most evident in the area of civic culture, such as flags, anthems, public holidays and honours. ${ }^{13}$ Yet this "new nationalism" did not bring about complete destruction of the concept of Britishness, as Hopkins implies, and nor was it a straightforward process. Rather, it involved a gradual re-negotiation of the relationship with Britain, and a slow and stumbling creation of new identities, which had in fact begun well before the decline of the British Empire and which remains unfinished in the twenty-first century. ${ }^{14}$ Contests over the form and content of national symbols, as well as over how best to realign the relationship with Britain as the imperial motherland re-oriented itself to Europe from the 1960s, were, at times, passionately fought.

Other scholars have also explored the relative influence of Britishness and nationalism in Australian identity and history. ${ }^{15}$ Russell McGregor critiqued both the radical nationalist view and a " "multiple identities' interpretation" that posited that people had "two discrete identities, British and Australian, with little discord or tension or, indeed, interaction of any kind between them" ${ }^{16}$ He argued instead for a "composite" British-Australian identity in which "the amalgamation of both [was] essential to Australians' sense of nationhood". ${ }^{17}$ According to McGregor, "Britishness was an ethno-cultural principle to which late-nineteenth and early-twentieth century Australians were deeply committed, not as an alternative or impediment to Australian nationalism but as a vital component of that nationalism". 18

More recently, debate over the relative weight of Australian nationalism and Britishness in Australian history and identity was revived in a symposium in History Australia. Christopher Waters argued that Meaney "went too far" in asserting the pre-eminence of Britishness in Australian history and identity. ${ }^{19}$ Focusing on the idea that there was between the end of World War I and the 1970s "a global Age of Decolonisation", he suggested that Australians like others around the world "were subject to the great sweep of ideas and events driven by the Age of Decolonisation". ${ }^{20}$ Waters reminds us that "for some within the labour movement and the emerging university-educated elite, the idea of Australia as a nation was by the 1940s at the centre of their thinking”. ${ }^{21}$ Marilyn Lake argued that scholars need to "move beyond the analytic binary of 'Australian radical nationalism' ... and 'British

\footnotetext{
12 Stuart Ward, “The 'New Nationalism' in Australia, Canada and New Zealand: Civic Culture in the Wake of the British World”, in Kate Darian-Smith, Patricia Grimshaw and Stuart Macintyre, eds., Britishness Abroad: Transnational Movements and Imperial Cultures (Carlton, 2007), p.260.

${ }^{13}$ Curran and Ward, Unknown Nation, p.9. See also Ward, “The ‘New Nationalism’”, pp.231-63.

${ }^{14}$ Curran and Ward, Unknown Nation.

${ }^{15}$ Besides those mentioned above and below, see James Curran, “Australia at Empire’s End: Approaches and Arguments”, History Australia, Vol. 10, 3 (2013), pp.23-35; Jim Davidson, “De-Dominionisation Revisited,” Australian Journal of Politics and History, Vol. 51, 1 (2005), pp.108-113; Deborah Gare, "Britishness in Recent Australian Historiography”, The Historical Journal, Vol. 43, 4 (2000), pp.1145-55; Deryck M. Schreuder and Stuart Ward, eds., Australia's Empire (Oxford, 2008); Luke Trainor, British Imperialism and Australian Nationalism: Manipulation, Conflict, and Compromise in the Late Nineteenth Century (Cambridge, 1994); John Warhurst, "Nationalism and Republicanism in Australia: The Evolution of Institutions, Citizenship and Symbols”, Australian Journal of Political Science, Vol. 28, 4 (1993), pp.100-120; Christopher Waters, The Empire Fractures: Anglo-Australian Conflict in the 1940s (Melbourne, 1995).

${ }^{16}$ McGregor, “Necessity of Britishness”, pp.496-497.

${ }^{17}$ Ibid., p.507.

${ }^{18}$ Ibid., p.507.

${ }^{19}$ Christopher Waters, “Nationalism, Britishness and Australian History: The Meaney Thesis Revisited”, History Australia Vol. 10, 3 (2013), p.12.

${ }^{20}$ Waters, 'Nationalism, Britishness and Australian History,' 15.

${ }^{21}$ Waters, 'Nationalism, Britishness and Australian History,' 16.
} 
race patriotism"” to consider also "a transnational Anglo-Saxonism ... that underpinned strong identification on the part of an influential group of Australian radical liberals ... with the independent New World republic of the United States” prior to World War I. ${ }^{22}$ In a subsequent issue of the journal, Meaney responded to Waters and Lake, reasserting his arguments. ${ }^{23}$

We are drawn to agree with Waters that the case for the dominance of Britishness in Australian identity can be overstated. We are conscious, for example, that earlier forms of radical nationalism did not necessarily undermine a sense of Britishness, and were able to exist alongside and even within it. In this sense, we incline to McGregor's description of a composite British-Australian identity. Despite all this contention, however, it appears that there is a fairly widespread consensus about the decline of Britishness as a major factor in Australia's national identity from the 1960s. Curran and Ward's explanation of how and why these issues came to a head in the 1960s and 1970s is persuasive, and the two case studies presented in this article certainly support their general argument. We seek to build on their approach, drawing out the longer history of the debates surrounding the honours system and the Australian of the Year award. The analysis that follows also reveals the complex interplay of a range of political and cultural factors shaping the development of these two institutions. Tangled together with the emergence of a more exuberant nationalism and the continuation of emotional and cultural ties to Britishness were party political struggles, tussles over states' rights, and competing visions of just what an Australian nation should look like.

\section{Australia's National Honour: The Order of Australia, 1975}

Until the creation of uniquely Australian honours in the 1970s, Australians received distinctions through the British imperial system. Imperial honours were a source of considerable political debate throughout the twentieth century, partly because the two major parties adopted different policies and practices regarding them. It was part of the Australian Labor Party's federal platform to end recommendations for imperial honours as early as $1918 .{ }^{24}$ Besides affirming the aim at subsequent party conferences, however, little action seems to have been taken to accomplish this goal. State and federal Labor governments generally refused to make recommendations for knighthoods (or for their female counterpart, damehoods) but they did sometimes recommend the conferral of awards that did not bestow titles, such as the lower grades of the Order of the British Empire - the CBE (Commander of the Order of the British Empire), OBE (Officer) and MBE (Member). While there were some attempts to end, or to severely restrict, the bestowal of titular awards, especially in the wake of honours-selling scandals in England in the 1920s, these were limited and not particularly successful.

The ALP's stance led to a situation in which honours - or at least titular ones - were granted or not in each State and federally depending on which party held power. When the New Year honours were announced in 1966, for instance, the Australian observed that New South Wales had a State honours list "for the first time in 25 years," after a Liberal government had taken office, while in South Australia the election of a Labor government meant that "for the first time in 32 years" there were no State honours. ${ }^{25}$ As Don Aitkin observed in the Canberra Times in 1968, the major parties' differing approaches led to "something of an imbalance" between the various States, with Victoria and South Australia doing better in the knighthood stakes than New South Wales and Queensland. ${ }^{26}$

\footnotetext{
${ }^{22}$ Marilyn Lake, “British World or New World? Anglo-Saxonism and Australian Engagement with America”, History Australia Vol. 10, 3 (2013), p.36.

${ }^{23}$ Neville Meaney, “The Problem of Nationalism and Transnationalism in Australian History: A Reply to Marilyn Lake and Christopher Waters”, History Australia Vol. 12, 2 (2015), pp.209-231. Waters has also responded to Meaney’s response. Christopher Waters, “A Reply to Neville Meaney”, History Australia Vol. 12, 2 (2015), pp.232-237.

${ }^{24}$ A Matter of Honour: The Report of the Review of Australian Honours and Awards (Canberra, 1995), p.13.

25 "Honors for Herron, Paltridge and Bolte", Australian, 1 January 1966, p.1.

${ }^{26}$ Don Aitkin, “Between the Lines”, Canberra Times, 16 October 1968, p.2.
} 
The landscape in relation to honours in Australia changed significantly in the 1970s, with the creation of a national system. Yet although this idea gained particular ground from the 1960s, it was not entirely new. Perhaps the earliest proposal for a uniquely Australian honour was a 1911 suggestion that Australia create its own "Order of the Wattle Blossom.” The author of this proposal was William Sowden, the editor of the South Australian Register and a prominent member of the Australian Natives' Association. Politically a Liberal, Sowden himself received an imperial honour in 1918, when he was knighted. He was a vigorous promoter of Australian-born governors and Australian civic symbols, suggesting also the replacement of "three cheers" with "three cooees". ${ }^{27}$ While acknowledging that imperial titles were "a real bond of Empire," Sowden had argued that Australia should have its own order, intended to recognise non-political services, as it "need[ed] more demonstrations of sentiment". ${ }^{28}$ Nearly forty years later, in late 1949, Ben Chifley's Labor government approved the idea of creating national honours, and a cabinet sub-committee formed to consider the matter. The scheme was dropped, however, after Labor was removed from power at the 1949 election. $^{29}$

In the 1960s Labor politicians raised the possibility of creating a new national honour several times in questions in Parliament. In May 1967, for instance, Gough Whitlam suggested that awards in the "archaically named” Order of the British Empire caused “embarrassment to [Australia's] diplomats and servicemen in South East Asia", and asked Prime Minister Harold Holt if he had observed Canada's recent creation of its own national honours. ${ }^{30}$ By this time, Stuart Ward has argued, “[t]he task of revealing Australians to themselves - of shoring up the symbols and sentiments of Australian nationhood - had become a legitimate rationale for legislative action". ${ }^{31}$ Indeed, there were signs of a degree of bipartisanship towards the idea of creating national honours. Liberal Prime Minister John Gorton requested in May 1970 that the concept be developed. A proposal "along the lines of the Canadian system" was produced, but not pursued. ${ }^{32}$

Upon taking office as prime minister in 1972, Whitlam refused to recommend Australians for imperial honours and set in train the development of a system of national honours. ${ }^{33}$ Australian officials travelled to Canada to learn about the administration of the Canadian scheme, and these discussions shaped the emerging Australian system. ${ }^{34}$ In late 1974, the press reported that Whitlam intended to ask the Queen to approve new Australian awards, and, more provocatively, to cease bestowing imperial honours recommended by the State governments. ${ }^{35}$ Assent to the first of these requests was forthcoming, and the Order of Australia was instituted in 1975. Modelled on the Order of Canada, it had three levels - Companion (AC), Officer (AO) and Member (AM) - and it did not

\footnotetext{
${ }^{27}$ Carl Bridge, “Sowden, Sir William John (1858-1943)”, Australian Dictionary of Biography, National Centre of Biography, Australian National University, <http://adb.anu.edu.au/biography/sowden-sir-william-john8593/text15005>; Will J. Sowden, An Australian Native’s Standpoint (London, 1912), pp.121-22.

${ }^{28}$ Sowden, Australian Native’s Standpoint, pp.115-16.

${ }^{29}$ A Matter of Honour, p.13.

${ }^{30}$ Gough Whitlam, Parliamentary Debates, House of Representatives (Commonwealth of Australia), 18 May 1967. Whitlam raised the issue again in September 1967 and May 1969. Gough Whitlam, Parliamentary Debates, House of Representatives (Commonwealth of Australia), 5 September 1967; Gough Whitlam, Parliamentary Debates, House of Representatives (Commonwealth of Australia), 29 May 1969.

${ }^{31}$ Stuart Ward, “'Culture up to our Arseholes’: Projecting Post-Imperial Australia”, Australian Journal of Politics and History, Vol. 51, 1 (2005), p.59.

${ }^{32}$ Malcolm Hazell, “The Australian Honours System: An Overview”, in Michael Jackson, ed., Honouring Commonwealth Citizens, Proceedings of the First Conference on Commonwealth Honours and Awards, Regina, Saskatchewan, Canada, 27-29 April 2006 (Toronto, 2007), p.38.

${ }^{33}$ Gough Whitlam, The Whitlam Government 1972-1975 (Ringwood, 1985), pp.141-42.

${ }^{34}$ Hazell, “The Australian Honours System”, p.39.

35 “PM to Ask Queen for Ban on State Honours”, Sydney Morning Herald, 1 December 1974, p.3; "PM Wants Royal Veto on Honours”, West Australian (Perth), 2 December 1974, p.1.
} 
include titles. In an effort to remove honours from political influence, the process of selection was also different. Rather than decisions on the list being made by the prime minister, or the premier in the case of State recommendations, nominations would be assessed by an independent Council, which would recommend awards directly to the governor-general. Speaking about the new Order in the House of Representatives in May, the member for Fraser, Ken Fry, stated that introducing "our own independent manner of honouring Australians who have rendered distinguished and unselfish service to their country" was a "logical development". "Whatever members of the Opposition may think", Fry remarked, he considered it "anachronistic and subservient to have to depend on an imperial system of orders of chivalry to honour Australia's most distinguished sons and daughters". ${ }^{36}$

Changes to honours were part of a broader set of reforms under Whitlam, intended to reflect Australia's shifting relationship with the United Kingdom. During his prime ministership, the Queen's style and titles were changed to describe her as "Queen of Australia”, and “Advance Australia Fair” replaced (albeit not finally) "God Save the Queen” as the national anthem. ${ }^{37}$ These moves were envisaged as recognising an Australian nationhood and national identity. In Whitlam's words, they were "to put our relationship [with Britain] on a more mature and contemporary basis and to reflect the development of a more independent Australian identity in the world". ${ }^{38}$ At around the same time, similarly prompted by the declining relevance of Britishness as a sentimental and symbolic foundation of identity as empire receded, and by the rise of the "new nationalism", other former British dominions were making similar moves. Canada had created its own order in 1967, while New Zealand's first national awards, the Queen's Service Order and Medal, were instituted in 1975. Across the British world, the decades of the 1960s and 1970s seemed a felicitous moment for the creation of new honorific symbols. ${ }^{39}$

Initial reactions to the Order of Australia were ambivalent. In Melbourne, the Herald considered it "sensible and dignified", and "a good deal more realistic ... than membership of an order of an empire which no longer exists", and the Age's Claude Forell, while sceptical about honours in general, declared the new order "less inherently absurd" than continuing to appoint people to an order of "a non-existent empire" or other "overseas orders of chivalry". ${ }^{40}$ The Sydney Morning Herald hedged its bets, stating that there was "not the slightest reason" why Australia, being "a sovereign independent commonwealth", should not have its own order, but also asserting that the "average Australian" might not like "the pretence" that imperial honours were not being disparaged. ${ }^{41}$ The Australian was similarly unsure, approving the assertion that Australia had "come of age as a nation", but thinking the new order was bound to be branded "the Ocker award", and, for a time at least, to "feel a bit second-rate". ${ }^{42}$ Other newspapers were simply unimpressed. One reportedly thought the government was "behaving like Bazza McKenzie", wanting "to proclaim its Australianism to the point of chauvinism”, and there were "[s]nide references to Gough's Gongs and the Order of the Wombat”. ${ }^{43}$ Meanwhile, a Gallup poll reportedly showed that forty-four per cent of Australians

\footnotetext{
${ }^{36}$ Ken Fry, Parliamentary Debates, House of Representatives (Commonwealth of Australia), 29 May 1975.

${ }^{37}$ Whitlam, Whitlam Government, pp.131, 144-45.

${ }^{38}$ Ibid., p.131.

${ }^{39}$ For further discussion of the creation of national honours in Canada, New Zealand and Australia, and of the impulses of "new nationalism” and de-dominionisation, see Karen Fox, “An 'imperial hangover’? Royal Honours in Australia, Canada and New Zealand, 1917-2009”, Britain and the World, Vol. 7, 1 (2014), pp.6-27.

40 “Order of Australia Fits Our Identity”, Herald (Melbourne), 18 February 1975, p.4; Claude Forell, "New Honors and Old Pretensions”, Age (Melbourne), 20 February 1975, p.8.

41 “E and OE”, Sydney Morning Herald, 19 February 1975, p.6.

42 "Why We Need Our Own Honors”, Australian, 19 February 1975, p. 8; "What Papers Think About New Honours”, West Australian (Perth), 21 February 1975, p.5.

43 "What Papers Think About New Honours", p.5; Jane Brumfield, “To the Top with Honors”, Australian, 18 February 1980, p.7; “Gough’s Gongs!” Sun (Sydney), 12 December 1975, p.3.
} 
favoured the new honours, and forty-four per cent British awards; political division was evident in the responses, with fifty-nine per cent of ALP voters preferring Australian honours, compared to thirty-two per cent of Liberal-Country Party voters. ${ }^{44}$

There was less success in achieving the end of State recommendations for imperial honours. State governments divided on party lines over whether they would make use of the new Order of Australia, or ignore it and continue to recommend for imperial honours. In Tasmania and South Australia, Labor governments adopted the new system. The four non-Labor States, however, were quick to reject the Order. The Victorian Liberal premier, Rupert Hamer, declared his State would not use the Australian awards, as his government had not been consulted and in any case favoured imperial awards, and Tom Lewis, the Liberal premier of New South Wales, said that "[u]nder no circumstances will NSW be accepting the new system". ${ }^{45}$ In Western Australia, Liberal premier Sir Charles Court said that his government would continue to submit honours lists directly to the Palace. ${ }^{46}$ Queensland's National Country Party premier, Joh Bjelke-Petersen, asserted that "[w]e stand by the present ... system and will continue to use it". ${ }^{47}$ The new Order, he remarked dismissively, would not be "within a cooee of the traditional honours", which were envied by other countries. ${ }^{48}$ As Curran and Ward have pointed out, for State governments such as Bjelke-Petersen's, honours were not so much a matter of national identity and independence as "another battle in the war over states' rights", which had intensified during Whitlam's prime ministership. ${ }^{49}$ The result, however, as Reg Foster ("Onlooker") observed in the Sydney Morning Herald, was that "[t]wo founts of honour [would] flow”, one from Canberra and one from London. "How long", Foster asked, would the non-Labor State governments "persist in holding out"? And what would happen if the Whitlam government lost office before the Order was "fairly established"? ${ }^{50}$ The answer to the last question would not be long in coming.

\section{6-1992: A Patchwork Honours System}

The Order of Australia had barely begun its life when a change of government put its continued existence in doubt. In the event, Liberal Prime Minister Malcolm Fraser did retain the Order after he took office in 1976, but his government made significant changes to it. An upper level of knighthood and damehood (AK/AD) was added, and an associated medal (OAM). These changes were intended to afford a more comprehensive range of honours than the initial three grades had provided. The OAM would allow recognition of those who had given long and valuable service in some area, but who would not have been appointed as Members, while the AK/AD would be a rare award given to those whose service had been exceptional. There seems to have been little controversy over the creation of the medal, but the addition of titles was another matter. Four people who had been appointed to the Order already - educator Jean Blackburn (AO), Brotherhood of St Laurence director David Scott (AO), economist and public servant H. C. "Nugget" Coombs (AC) and author Patrick

\footnotetext{
44 “Keep UK Honors, Say 65\%”, Herald (Melbourne), 22 March 1975, p.2. In a separate question, respondents were also asked if imperial honours should stay; sixty-five per cent answered in the affirmative, and twenty-nine per cent wished them to be abandoned. "Keep UK Honors, Say 65\%”, p.2.

${ }^{45}$ Michelle Grattan, “First New Honors in June”, Age (Melbourne), 18 February 1975, p.1; “Non-Labor Premiers Reject Honours Plan”, Sydney Morning Herald, 18 February 1975, p.13; Ian Frykberg, “New Honours System”, Sydney Morning Herald, 18 February 1975, p.1.

${ }^{46}$ Russell Schneider, “New National Honors to be Launched in June”, Australian, 18 February 1975, p.1.

47 ““States Wrong to Ignore New Honors List””, Australian, 19 February 1975, p.3.

48 “Non-Labor Premiers Reject Honours Plan”, p.13.

${ }^{49}$ Curran and Ward, Unknown Nation, p.217.

${ }^{50}$ Onlooker, “Candid Comment”, Sydney Morning Herald, 23 February 1975, p.42.
} 
White (AC) - resigned in protest. ${ }^{51}$ Scott was quoted stating that he did not think the Order should include "titles of distinction", while White said in a statement released to the press that it had been established as "a democratic order", and the addition of titles was "really quite contrary to the original concept". 52

Fraser also resumed federal government recommendations for imperial honours, implicitly raising a question over the whole rationale for the Australian order. The major issue involved in resuming imperial honours was how the two systems should mesh. Fraser had instructed that they should operate in parallel, but with the caveat that if there were problems realising that aim, British honours should be immediately restored. ${ }^{53}$ Among the difficulties considered by the public servants tasked with implementing this directive were that the reintroduction of imperial honours might cause the Order of Australia to atrophy, the nature of the Prime Minister's role in recommending or nominating individuals for each system and the potential for a proliferation of awards. ${ }^{54}$

The States, predictably, responded along party lines. South Australia's Labor premier, Don Dunstan, refused to return British honours to South Australia, describing it as "inappropriate" to give awards in "the order of the non-existent British Empire". ${ }^{55}$ From Western Australia, on the other hand, Court wrote that he was greatly pleased at the resumption, while also observing that his State had continued to use British honours anyway, as it had the right to do as a sovereign State. ${ }^{56}$ Public responses varied. Forell, in the Age, remarked that Australia now had "a choice of four national anthems, two honours systems and four official titles for the national Government". Such "diversity", he argued, was both politically "divisive" and gave the impression that Fraser, or his government, was "indecisive". 57

In the following years, the honours system was caught in a struggle over identity, torn between the reality of an independent Australian nation and the continuance of ties to Britain, which retained a powerful imaginative hold for many people. This struggle was partly expressed through the major parties' different choices about whether and how to use the alternative systems of awards. The existence of such parallel systems added a new flavour to longstanding tensions between State and federal governments over who had the right to make which recommendations. In January 1977, acting South Australian Labor premier Des Corcoran wrote to Fraser to express irritation that a South Australian public servant had received a British honour on the federal list. By nominating a State public servant, he argued, the federal government had appropriated a privilege belonging to the State

\footnotetext{
51 “Honour Returned”, Canberra Times, 7 July 1976, p.8; “Another Protest at Titles”, Canberra Times, 23 June 1976, p.8; “Dr Coombs Resigns From Order of Australia”, Sydney Morning Herald, 11 June 1976, p.1; A Matter of Honour, p.20.

52 “Another Protest at Titles”, p. 8; “No Knights for Patrick White”, Sydney Morning Herald, 23 June 1976, p.24. White added a second reason: he had "no respect" for the Governor-General, Sir John Kerr, who was head of the Order. "No Knights for Patrick White”, p.24. For further discussion of attitudes to titular awards in Australia, and an analysis of the discourse of egalitarianism in debates over honours in Australia, Canada and New Zealand, see Karen Fox, ““A pernicious system of caste and privilege’: Egalitarianism and Official Honours in Australia, New Zealand and Canada”, History Australia, Vol. 10, 2 (2013), pp.202-226.

${ }^{53}$ National Archives of Australia: Department of the Prime Minister and Cabinet; A1209, Correspondence files, annual single number series, 1957-; 1976/2235 Part 2, Imperial/Australian honours system - Policy, 1976-1976; letter to Secretary from Malcolm Fraser, 25 February 1976.

${ }^{54}$ National Archives of Australia: Department of the Prime Minister and Cabinet; A1209, Correspondence files, annual single number series, 1957-; 1976/2235 Part 2, Imperial/Australian honours system - Policy, 1976-1976.

55 “Era of ‘Take Your Pick’ Pomp and Pageantry”, Age (Melbourne), 26 January 1976, p.9.

${ }^{56}$ National Archives of Australia: Department of the Prime Minister and Cabinet; A1209, Correspondence files, annual single number series, 1957-; 1976/2235 part 1, Imperial/Australian honours system - Policy, 1975-1976; letter to J. M. Fraser from Charles Court, 22 January 1976.

${ }^{57}$ Claude Forell, “Ritual Confusion Divides a Nation”, Age (Melbourne), 29 January 1976, p.8, emphasis removed.
} 
government. Insult was added to injury by the fact that it was an imperial honour, the State government having ended the use of British honours some years previously. ${ }^{58}$

Besides the issue of which parties supported which system, there was also the question of which nominees were willing to accept which awards. For some, Australian honours reportedly "were considered second prize, not quite having the cachet of something from the Old Country". ${ }^{59}$ For others, especially those who supported an Australian republic, a national honour was acceptable in a way that an imperial one was not. Writer Kylie Tennant, for example, twice declined an OBE, but accepted an AO. ${ }^{60}$ After the award was announced, one of the congratulatory letters she received noted that the distinction was not only merited, but acceptable to republicans. ${ }^{61}$ (Approval of the Order of Australia as suitably nationalist was not unanimous. In 1984, Tennant's fellow novelist, Xavier Herbert, refused the honour because he considered it "still an Imperial award” from the Queen of England, "even if she were also the Queen of Australia". ${ }^{62}$ ) As the years passed, however, support for the Order of Australia appeared to be growing. By 1979, the Sydney Morning Herald was reporting that its latest survey showed firm backing for Australian honours, either together with imperial honours (thirty-eight per cent) or alone (thirty-nine per cent), but barely any desire for British honours by themselves (five per cent). Yet a political divide remained, with support for Australian honours "much stronger among Labor voters", and Liberal and National Country Party voters "much more inclined to favour either ... joint British and Australian honours or ... British honours only" ${ }^{63}$

Another change took place in 1986, when titles were removed from the Order of Australia by Bob Hawke's Labor government. Commenting on this move, the Sydney Morning Herald suggested that the Hawke government was making odd decisions in an effort "to create a nationalist mood in Australians" ahead of the Bicentennial. To abolish titles, the Herald thought, merely invited a future Coalition government to bring them back, as well as potentially causing a renewed focus on imperial honours from State governments. But what was "most irritating", the paper declared, was the "forcefed patriotism". Arguing that there had not been any public pressure to eliminate titles from the Order, the writer attributed the decision to a "determination" on the part of the government to "create an aura of nationalism" for the Bicentenary. ${ }^{64}$

The final initiative for ending the award of imperial honours in Australia came from the Queen herself. In February 1990 a letter from her private secretary to the governor-general explained Her Majesty's view that since no Australian government had made recommendations for British honours in the most recent list, it was an appropriate time for Australia to consider using only its own system. ${ }^{65}$ That month New South Wales Liberal premier Nick Greiner, who had promised in his election campaign not to nominate for imperial honours, said in a radio interview that the Queen had suggested to him that "it was unseemly to have a lottery depending on which party was in power", and that "she would prefer a commitment to the Order of Australia”. ${ }^{66}$ Earlier, in 1988, Greiner had reportedly said

\footnotetext{
${ }^{58}$ National Archives of Australia: Department of the Prime Minister and Cabinet; A1209, Correspondence files, annual single number series, 1957-; 1976/2235 part 3, Imperial/Australian honours system - Policy, 1976-1977; letter to J. M. Fraser from Des Corcoran, 6 January 1977.

${ }^{59}$ Sally Loane, “Australian Honors Stand Alone at Last”, Age (Melbourne), 29 May 1991, p.2.

${ }^{60}$ Kylie Tennant, The Missing Heir: The Autobiography of Kylie Tennant (South Melbourne, 1986), p.165.

${ }^{61}$ Dal Stivens to Kylie Tennant, 10 May 1980, Papers of Kylie Tennant, 1891-1989, MS10043/14/106, National Library of Australia, Canberra.

62 “Xavier Herbert Knocks Back a Royal Honour”, Sydney Morning Herald, 9 June 1984, p.5.

63 “Strong Backing for Aust Honours System”, Sydney Morning Herald, 26 December 1979, p.2. The remaining sixteen percent thought "no honours of any kind should be awarded”. "Strong Backing for Aust Honours System”, p.2.

64 “Definitely Beyond the Call of Duty”, Sydney Morning Herald, 30 January 1986, p.10.

${ }^{65}$ Hazell, “The Australian Honours System”, pp.41-2.

${ }^{66}$ Luis M. Garcia, “An End to Imperial Honours ‘Lottery’”, Sydney Morning Herald, 15 February 1990, p.3.
} 
"that Australia had grown up enough to settle on one system of local honours". ${ }^{67}$ It took some time to secure the agreement of all States, but in 1992 Prime Minister Paul Keating announced that no more recommendations would be made by either State or federal governments. ${ }^{68}$ The decision was not universally popular. Sir James Killen, a former minister of defence, expressed his unhappiness to the press: "I'm puzzled as to why there's this anxiety to get rid of the past", he said, remarking on the long history of British honours, and the British heritage of Australia's parliamentary and legal systems. ${ }^{69}$

Even after this apparently definitive step, honours continued to be contested. A major review of the system was undertaken in 1995. The minister for administrative affairs, Frank Walker, thought Australians wanted change. The review committee, he said, would advise "how to put a truly national stamp on [the] system". ${ }^{70}$ Debates continue to this day as to whether Australia's honours are yet a "truly Australian" form of recognition. Particular criticism has been directed at the practice of announcing awards on the Queen's Birthday holiday, and more recently at Prime Minister Tony Abbott's restoration of knighthoods and damehoods to the Order of Australia in 2014. The difficulty, however, must lie in defining what it may mean for honours to be "truly Australian" ${ }^{71}$ Is it about who awards them, who receives them or what they look like? Is it about when they are announced, what they are called or whether the community accepts them as such? These issues have plagued the honours system across the twentieth century, and they have never been fully answered. Moreover, many of the same questions might be posed in relation to the Australian of the Year award.

\section{The Australian of the Year Award}

The announcement that Prince Philip would receive a knighthood in the Order of Australia was broadly lambasted, but one of the more prominent criticisms was that the controversy had overshadowed the naming of the 2015 Australian of the Year, the anti-domestic violence campaigner Rosie Batty. ${ }^{72}$ Although these two forms of national recognition have quite separate histories, they are often conflated due to the coincidence of their announcement on Australia Day. Moreover, in recent years they have competed for media attention. Historically, however, the Australian of the Year award has been a less substantial and less overtly political institution than the official honours system. Curran and Ward contend that for two decades following its inauguration in 1960 the award was an obscure Melbourne initiative, little noticed beyond the Victorian press and of "entirely marginal status". ${ }^{73}$ While they are correct to highlight its Victorian origins and modest beginnings, we argue that Ward and Curran underestimate the significance of the award to their broader thesis about Australia's hesitant search for a post-imperial identity. The relevance of the award to issues of national identity was particularly evident in the 1970s, when it was embroiled in a protracted controversy that echoed concurrent debates about the Order of Australia, and highlighted the contested nature of Australian identity.

\footnotetext{
67 “Row Over Greiner’s Knight Shift”, Sydney Morning Herald, 9 January 1988, p.4.

${ }^{68}$ A Matter of Honour, pp.21-2.

69 “Keating’s Newest Anti-Royal Move Disturbs Knight”, Canberra Times, 7 October 1992, p.5.

${ }^{70}$ Frank Walker, Parliamentary Debates, House of Representatives (Commonwealth of Australia), 21 June 1995.

${ }^{71}$ A similar point has been made by John Warhurst: there is, he observed, “no objective measure of whether a nation’s institutions and symbols are sufficiently 'national' and appropriate for an independent nation”. Warhurst, "Nationalism and Republicanism”, p.117.

${ }^{72}$ For example, “Duke’s Knighthood a Blow to Abbott’s Leadership”, Canberra Times, 26 January 2015.

${ }^{73}$ Curran and Ward, Unknown Nation, p.192.
} 
The history of the Australian of the Year award is closely intertwined with the history of Australia's national day. ${ }^{74}$ The award's genealogy can be traced back to the Australian Natives' Association, a mutual society for Australian-born men, which had been a strong campaigner both for Federation and for the observance of a national day of celebration on 26 January. ${ }^{75}$ The Victorian branch of the ANA was particularly vocal in its support for what by 1930 it was calling “Australia Day”. By 1935 it had convinced the other States to follow its lead, and after World War II it established the first Australia Day Council, which strove to educate the public on the significance of Australia Day and to encourage celebrations. ${ }^{76}$ In subsequent years several more State-based Australia Day councils were established, and in 1957 they cooperated to form an umbrella body, the Federal Australia Day Council. ${ }^{77}$ Nevertheless, the Victorian council remained the key advocate for proper celebrations, as it was the best resourced and most active. It was to play a fundamental role in the early history of the Australian of the Year awards.

From 1951 until 1970 the chairman of the Victorian Australia Day Council was Sir Norman Martin, a former Country Party politician who had served as Victoria's Minister for Agriculture during World War II and subsequently as its Agent General in London. ${ }^{78}$ When Martin returned to Victoria and took on his new role, he declared that Australia was destined to become "the Britain of the southern seas”, and urged his compatriots to give "a little more thought” to Australia Day. ${ }^{79}$ In January 1960 he launched the annual celebrations by announcing the introduction of a new award, which was briefly styled the "Australia Day Foundation Award". The honour would be presented to the person judged by a special panel to be the "Australian of the Year". Almost immediately, the more descriptive second title emerged as the preferred name, but the link with Australia Day remained strong. Martin told Melbourne's Herald that "Australia's national day should be the time chosen for 'full and proper' recognition of an Australian who had made an outstanding contribution". ${ }^{80} \mathrm{He}$ clearly hoped the award would help promote patriotic celebrations in January each year. From its very beginning, therefore, the Australian of the Year award was not simply an award for excellence, but a conscious attempt to promote a particular form of patriotic nationalism.

Martin explained that a distinguished selection panel would be assembled to place the award on "the highest possible plane". ${ }^{81}$ It was subsequently announced that this panel would consist of the Victorian premier, the Anglican archbishop of Melbourne, the vice-chancellor of Melbourne University, the lord mayor of Melbourne, and the president of the Victorian branch of the National Council for Women. Describing this all-Victorian selection committee in the Sydney Morning Herald, Reg Foster (“Onlooker”) dryly observed: “It won’t look so good if the choice should just happen to light on a Victorian first go off, even though 'nominations are to be sought from all over Australia'."82 In choosing an appropriate inaugural winner, the panel was certainly aided by the fact that its preferred candidate, the immunologist (and Victorian) Sir Macfarlane Burnet, had the recent

\footnotetext{
${ }^{74}$ For a fuller account of the history of the award see Samuel Furphy, Australian of the Year Awards: A Fiftieth Anniversary History (Parkes, A.C.T.: National Australia Day Council, 2010), also available online at $<$ http://www.australianoftheyear.org.au/the-awards/awards-history/> (accessed 22 April 2015).

${ }^{75}$ Elizabeth Kwan, Celebrating Australia: A History of Australia Day (2007),

$<$ http://www.australiaday.org.au/australia-day/history/> (accessed 21 April 2015).

${ }^{76}$ John Menadue, A Centenary History of the Australian Natives’ Association 1871-1971 (Melbourne, 1971), pp.19294; see also Kwan, Celebrating Australia.

77 Jeannie Churchill, Australia Day: A History, 1788 to 1996 (Sydney, 1996), p.23.

78 B. J. Costar, “Martin, Sir Norman Angus (1893-1978)”, Australian Dictionary of Biography, National Centre of Biography, Australian National University, <http://adb.anu.edu.au/biography/martin-sir-norman-angus-11074>.

79 “We’ll be Britain of the South”, Argus (Melbourne), 15 August 1951, p.5.

80 “We'll have an 'Australian of the Year”, Herald (Melbourne), 15 January 1960, p.5.

${ }^{81}$ Ibid.

${ }^{82}$ Reg Foster (“Onlooker”), “Man of the Year”, Sydney Morning Herald, 24 July 1960, p.38.
} 
endorsement of the Nobel Foundation in Sweden. Nevertheless, the existence of a supposedly national award chosen by a panel of Victorians was always going to be problematic. Initially, the principal challenge was promoting the award outside Victoria, but interest slowly grew until the 1965 Australian of the Year, the dancer Robert Helpmann, featured in a prominent article on page four of the Sydney Morning Herald. ${ }^{83}$ During the 1960s, the selection panel usually chose winners who had made an undeniable contribution on the world stage: Nobel prize winners (Burnett and Sir John Eccles), world-beating sportspeople (Jock Sturrock, Dawn Fraser, Jack Brabham and Lionel Rose) and internationally successful performers (Joan Sutherland, Helpmann, and the Seekers). These choices certainly helped promote the award beyond Victoria.

\section{Whose Australian of the Year?}

As the award's profile slowly increased, however, its close association with Victoria began to undermine its legitimacy. Consequently, in the 1970s two rival awards emerged to challenge the authority of the Victorian Australia Day Council. The first competitor was Rupert Murdoch's Australian newspaper, which introduced its own "Australian of the Year" award in January 1972, honouring the retired public servant and economist H. C. "Nugget" Coombs; the following year it gave its award to the new Prime Minister, Gough Whitlam. ${ }^{84}$ As a national (albeit small) newspaper, the Australian was well placed to promote its award as a truly national honour; it still exists today, despite various attempts by the organisers of the original award to cooperate with the newspaper and end the duplication. ${ }^{85}$

The introduction of a third Australian of the Year award in 1975 was of more serious concern to the Victorian council. On this occasion the challenger was the recently formed Canberra Australia Day Committee, which was an independent group of young and progressive Canberrans, who aimed to increase the profile of Australia Day in the national capital. Significantly, the Canberra committee was not affiliated with the other State-based Australia Day councils; it pursued its own goals in Canberra, which were often at odds with the prominent Victorian council. In particular, the Canberra committee was sympathetic to emerging forms of civic nationalism, while the Victorian council remained staunchly committed to Australia's constitutional ties with Britain. Australia's political climate in the 1970s nourished this division. In 1973 the Victorian Australia Day Council noted its opposition to the growing campaign to change the national flag and expressed concern at "trends to abolish the Monarchy, delete the oath of allegiance and also abandon the National Anthem" ${ }^{86}$

The founding chairman of the Canberra Australia Day Committee was a young public servant and former law student, Frank Boddy, who had a history of organising major public events. ${ }^{87}$ As a $21-$ year-old, he had been a driving force behind “Australiana 200 Years" - a re-enactment of significant moments in Australian history held at Canberra's Regatta Point in July 1970. A stated aim of this festival was "to prove wrong the theory that Canberra has no soul". ${ }^{88}$ In 1972 he organised a "beer festival” on the shore of Lake Burley Griffin for the Canberra Day festivities in March. ${ }^{89}$ At a public

\footnotetext{
83 “Helpmann as ‘Australian of the Year’”, Sydney Morning Herald, 15 January 1966, p.4.

${ }^{84}$ See http://www.theaustralian.com.au/news/nation/australian-of-the-year (accessed 24 February 2015).

${ }^{85}$ Warren Pearson, interview with Samuel Furphy, 27 March 2009.

${ }^{86}$ Australia Day Council (Victoria), Report of the Executive Committee, 1972-3, (Melbourne, 1973).

87 “Satisfied with 15,000”, Canberra Times, 18 June 1970, p.3.

${ }^{88}$ Christobel Muson, “A Soul is Born”, Canberra Times, 13 June 1970, p.19.

89 “Aircraft Landing in Park Approved”, Canberra Times, 22 February 1972, p.3.
} 
meeting in November 1973 he was elected chairman of a committee to organise Canberra's first official Australia Day festivities the following year. ${ }^{90}$

Boddy recalls that one of the committee's early campaigns was to make the Australian of the Year a truly national honour. He found, however, that the Victorian council was not interested in talking to his group. ${ }^{91}$ Significantly, the Victorian-based award had gained the endorsement of the Federal Australia Day Council in 1973, and the Victorian council argued for its legitimacy on that basis. ${ }^{92}$ The Federal council had been unsuccessful, however, in lobbying the Whitlam Government for support, expressing regret in 1975 that it had been unable "to interest the Prime Minister, or any other Minister in granting recognition and finance to our movement". ${ }^{93}$ In this context, the Canberra committee decided simply to introduce its own award.

In January 1975 the Canberra Australia Day Committee presented its first award to Major General Alan Stretton, the director-general of the Natural Disasters Organisation, who had risen to fame during the emergency response to Cyclone Tracey. The profile of the new award was further boosted by the fact that Prime Minister Gough Whitlam presented the honour to Stretton. ${ }^{94}$ It hardly seems a coincidence that Whitlam lent his support to the new award around the same time that he inaugurated the Order of Australia. Over the next few years, the Canberra committee made good use of the federal parliamentary press boxes to promote its award to the national media. ${ }^{95}$

Needless to say, the Victorian council was unimpressed. Boddy recalls that his committee was well aware that the duplication of the award was inappropriate, and also admits that the selection process for the Canberra award was hardly rigorous; but he says he and his colleagues were primarily motivated by their desire to see Australia Day organised at a national level, with proper links to the Federal government. In January 1976 the Canberra committee did not present a second award, an omission that Boddy attributes to simmering discontent following the dismissal of the Whitlam Government. ${ }^{96}$ During the 1975 constitutional crisis the committee had been starved of funds, forcing it to cancel its Australia Day celebrations. Citing “other commitments” Boddy temporarily resigned as chairman and publicly blamed the lack of celebrations on "the political instability at the end of last year". ${ }^{97}$ Soon afterwards, the Victorian council again received the endorsement of the Federal Australia Day Council for its award. Later in 1976, Boddy announced that the Canberra celebrations and award were to be revived. ${ }^{98}$ The duplication of the Australian of the Year award would last for three more years.

An analysis of press reports demonstrates the parochialism that characterised the duplication of awards. In 1977 the Canberra Times dedicated only six lines under the non-descript headline "Award" to the announcement on 17 January that Sir Edward "Weary” Dunlop would be honoured at an Australia Day ceremony in Melbourne. ${ }^{99}$ A more prominent article spanning three columns reported the Canberra-based “Award for Sir Murray Tyrrell” on 26 January. The journalist noted that

\footnotetext{
90 “Celebration for Australia Day”, Canberra Times, 27 November 1973, p.2; “National Day”, Canberra Times, 29 November 1973, p.3.

${ }^{91}$ Frank Boddy, interview with Samuel Furphy, 20 February 2009.

${ }^{92}$ Australia Day Council (Victoria), Report of the Executive Committee, 1974-5, (Melbourne, 1975).

${ }^{93}$ Ibid.

94 See, for example, “Stretton Gets Praise from PM”, Sydney Morning Herald, 24 January 1975, p.4.

${ }^{95}$ Frank Boddy, interview with Samuel Furphy, 20 February 2009; Eugene Petrie, interview with Samuel Furphy, 18 February 2009; Jack Fahy, interview with Samuel Furphy, 25 March 2009.

${ }^{96}$ Frank Boddy, interview with Samuel Furphy, 20 February 2009.

97 “Australia Day Plans Abandoned”, Canberra Times, 23 January 1976, p.7.

98 “Australia Day”, Canberra Times, 18 November 1976, p.11.

${ }^{99}$ Canberra Times, 18 January 1977, p.3.
} 
Tyrrell's honour was "no less worthy in the light of the confusion engendered" by the existence of multiple awards, but that this situation had led Boddy "to explain several times, informally and with some patience, that he was an advocate of a national award". ${ }^{100}$ In Melbourne, the Age reported both the announcement of Dunlop's award on 17 January and its presentation on Australia Day, but overlooked Tyrrell's honour. ${ }^{101}$

The conflict between the two Australia Day organisations became more prominent in 1978. The Victorian council, which had usually announced its award about ten days before its Australia Day luncheon, shifted its announcement to the national day. Presumably it recognised that the Canberra award had benefited from the publicity surrounding Australia Day celebrations. At around the same time, the Canberra committee began calling itself the Canberra Australia Day Council, presumably to bolster its status, although it also found its Federal Government funding greatly reduced. ${ }^{102}$ Meanwhile, Boddy had become a prominent campaigner for self-government in the Australian Capital Territory; the Canberra Times columnist "Gang Gang” described him as a "tireless collector of causes". ${ }^{103}$ With the awards now announced on the same day, the conflict was descending into farce. Boddy recalls that he and the Liberal senator David Hamer, chairman of the Victorian council, proclaimed the merits of their competing awards during a prime time television debate moderated by Mike Willesee. ${ }^{104}$ When the Victorian council honoured the national president of the Country Women's Association, Raigh Roe, Senator Hamer proclaimed: "This is the real Australian of the Year". He added that he was "most annoyed" at the Canberra choice of the West Australian businessman Alan Bond. ${ }^{105}$

The Australian of the Year award had become embroiled in a political debate about Australian nationalism. Certainly, state rivalries played a role, as it was unsustainable that the Victorian premier should play such an important role in an awards program that had become nationally significant. An equally important cause of the conflict, however, was the contrasting visions for Australia Day promoted by the Victorian and Canberra councils. The Victorian body was conservative on issues of Australian nationalism, supporting the monarchy and opposing a new national anthem; it was also linked to the Liberal Party through its chairman, Senator David Hamer, a brother of the Victorian premier, Rupert Hamer, who chaired the award selection committee and was a vocal opponent of the Order of Australia. The Canberra council was less overtly political, but was nonetheless aligned with the new nationalist sentiment of Whitlam. Boddy later recalled: "Our colours were green and gold; the Victorian group was red, white and blue". ${ }^{106}$ Similarly, Boddy's successor as president of the Canberra council, Jack Fahy, recalled: "We were a forward moving group that moved away from salute the flag and have a breakfast". ${ }^{107}$

Curiously, the choices for the two rival awards did not always reflect these political divisions. The Canberra council was undoubtedly parochial and arguably quite conservative in its choices, notably in 1977 when it honoured Tyrrell, the long-serving official secretary to the governor-general. Meanwhile, despite the conservative leanings of the Victorian council, its selection panel produced an often-surprising list of winners, notably in the late 1970s when Rupert Hamer led a panel that was

\footnotetext{
100 “Award for Sir Murray Tyrrell”, Canberra Times, 27 January 1977, p.3.

101 “A Vote for Yesterday’s Heroes”, Age (Melbourne), 18 January 1977, p.19; “Sir John Savors the Flavor of a Free Lunch”, Age (Melbourne), 27 January 1977, p.6.

102 “Celebration a '20th-century spectacular””, Canberra Times, 24 January 1978, p.3; “Australia Day Pageant on a Shoe String”, Canberra Times, 25 January 1979, p.3.

103 Gang Gang, “Of Bodies Politic, Reds and Beds”, Canberra Times, 23 March 1978, p.3.

${ }^{104}$ Frank Boddy, interview with Samuel Furphy, 20 February 2009.

105 "WA Woman Australian of the Year", Sydney Morning Herald, 27 January 1978, p.3.

${ }^{106}$ Frank Boddy, interview with Samuel Furphy, 20 February 2009.

107 Jack Fahy, interview with Samuel Furphy, 25 March 2009.
} 
progressive in its choices, naming the sixth female winner and the third Aboriginal winner. Indeed, 1979 provides an interesting year to compare the two awards, as Aboriginal men won both honours: the Canberra council chose the first Aboriginal senator, Neville Bonner, who was a member of the Liberal Party, while the Victorian council named a more radical Aboriginal leader in land rights advocate Galarrwuy Yunupingu. This suggests that the dispute was not so much over who was chosen, but over who did the choosing, and whose particular vision for Australia Day would benefit from the public profile offered by the award.

The press noticed the juxtaposition of Bonner and Yunupingu, but was once again parochial in its coverage. On Australia Day the Canberra Times featured the front-page headline "Bonner named Australian of the Year". The following day a second headline on page 3 proclaimed "Bonner's role 'reminder of Australia's other nation'”; in a footnote to this article, it noted only briefly the selection of Galarrwuy Yunupingu by the Melbourne-based committee. ${ }^{108}$ In Melbourne, a picture of Yunupingu in the Herald was accompanied by the headline "Meet the Real Top Man". ${ }^{109}$ Perhaps predictably, the Sydney Morning Herald focused on the division, giving most prominence to the Melbourne award, but noting Yunupingu's strong criticism of the Canberra choice: "By selecting their own do-gooder," Yunupingu had remarked, "they're breaking down the spirit of Australia as a nation". ${ }^{110}$ Similarly, the Australian (which of course had a vested interest in ridiculing both awards) proclaimed in a front-page headline: “Cold Turkey and Squabbles for Australia’s Birthday”. ${ }^{111}$

\section{The National Australia Day Council}

The impasse was resolved only when the Fraser Government created the National Australia Day Council in October 1979. ${ }^{112}$ With proper links to the Federal Government, it was able to take charge of the situation and resolve the dispute. The Canberra council, which had achieved its goal of Federal government interest in Australia Day, agreed to discontinue its rival award. In January 1980 the Victorian council named its last Australian of the Year, the naturalist and television presenter Harry Butler. In April 1980 the new national council, chaired by the athlete Herb Elliot, held an Australia Day Forum, attended by delegates from the various State-based councils. The old Federal Australia Day Council was disbanded and links between the National Australia Day Council and the various State councils were established. A key resolution at the meeting was that responsibility for the Australian of the Year award should be transferred to the new national body. ${ }^{113}$

Surviving records do not reveal how willingly the Victorian council surrendered the award. One suspects it would have been less likely to cooperate with a new national council had it been introduced by Whitlam. The Victorian council's influence was further curtailed two years later, when the newly elected Victorian Labor Government created a new Australia Day Committee within the Premier's Department, which soon replaced the older council in the official national network. ${ }^{114}$ The Victorian

\footnotetext{
108 “Bonner Named Australian of the Year”, Canberra Times, 26 January 1979, p. 1; “Bonner’s Role 'Reminder of Australia’s Other Nation’”, Canberra Times, 27 January 1979, p.3.

109 “Meet the Real Top Man”, Herald (Melbourne), 26 January 1979, p.6.

110 “Yunupingu is Australian of Year - for Ranger Role”, Sydney Morning Herald, 27 January 1979, p.3.

${ }^{111}$ Australian, 27 January 1979, p.1, quoted in Curran and Ward, Unknown Nation, p.293.

112 The new body was originally called the National Australia Day Committee, but became the Council in the 1980s.

113 Minutes of the "National Australia Day Forum”, 12/13 April 1980, Ephemera Collection, Australia Day file, National Library of Australia.

114 The Australia Day Council (Victoria) was dis-endorsed by the NADC in 1982, prior to the election of the Federal Labor Government. “Executive Directors Meeting, 26-27 July 1982”, C4688/1, Directors Meetings Folders, Box 13, National Archives of Australia.
} 
council was thus excluded from an official Australia Day role; it became known as a conservative organisation, which presented silver spoons to babies born on 26 January.

Meanwhile, the new national council had revamped the selection procedure for the Australian of the Year award. ${ }^{115}$ However, despite rigorous attempts to create an independent selection panel, the first choice of winner was controversial. Details leaked to the media prior to the announcement and the Sydney Morning Herald reported that conservative Liberals were "apoplectic" that the historian Manning Clark was rumoured to be the winner. ${ }^{116}$ To complicate matters, Clark had been nominated for the award by the Canberra Australia Day Council, which had a politically progressive influence on the new national council during its first year of operation. ${ }^{117}$ When the inaugural national chairman, Herb Elliot, resigned his position a few months later, the Home Affairs Minister, Ian Wilson, denied reports that Elliot had been dismissed because of the selection of Clark. ${ }^{118}$ The president of the Canberra council, Jack Fahy, also resigned. ${ }^{119}$

Despite a shaky start, the National Australia Day Council pursued its charter of promoting national celebrations on 26 January. Its first secretary, Frank Cassidy, recalls that the council gradually realised the importance of the Australian of the Year award to the promotion of Australia Day. The effect of this shift can be traced in the list of winners for the 1980s, which begins with worthy but less popular figures such as Sir John Crawford and Sir Edward Williams, before shifting noticeably to household names like Robert De Castella, Paul Hogan, John Farnham and Allan Border. Indeed, the commercialism of the 1980s almost saw the Australian of the Year award overwhelmed by corporate sponsors. ${ }^{120}$ In the early 1990s there was another period of more overt politicisation of the National Australia Day Council under the chairmanship of Phillip Adams, who barely concealed his republican aspirations and his desire to replace Australia Day with celebrations on 1 January, the anniversary of Federation. Adams resigned shortly after the election of the Howard Government in 1996.

\section{Conclusion}

Despite the coincidence of announcing recipients on Australia Day, the Order of Australia and the Australian of the Year award are in many ways quite different forms of recognition, with quite separate histories. Both, however, have been inextricably entangled in "the politics of national recognition". The two case studies offered in this article support the view of James Curran and Stuart Ward that the emergence of new national symbols in Australia was a fraught process, and that the gradual severing of ties between Britain and its dominions created a difficult environment for expressions of civic nationalism. Our analysis builds upon that of Curran and Ward, suggesting that while Britain had embraced Europe, and its Empire had declined by the 1970s, Australia's historical and emotional connection to Britain was surprisingly persistent in the realm of civic culture and identity. This was particularly true of the institutions we have analysed, in which expressions of national identity were keenly contested as much as ambiguous. Our research also suggests that, for the history of the honours system in particular, the post-war decline of the British Empire was a catalyst rather than a determining factor. Opposition to imperial honours was not entirely a postimperial phenomenon; though it strengthened in the wake of empire, such opposition had been expressed in the past, and proposals had been made for a national system as early as 1911. Finally,

\footnotetext{
1151980 Australian of the Year brochure, State Library of Victoria, Subject File, “Australian of the Year”.

116 “Awards Anger”, Sydney Morning Herald, 25 January 1981, p.134.

117 Jack Fahy, interview with Samuel Furphy, 25 March 2009.

118 “‘Mischievous’ Report”, Sydney Morning Herald, 28 August 1981, p.12.

119 Jack Fahy, interview with Samuel Furphy, 25 March 2009.

${ }^{120}$ Phillip Adams, interview with Samuel Furphy, 16 December 2008.
} 
our case studies demonstrate a more complicated set of political influences than differences between republicanism and imperial loyalty, or competing visions of Australian identity; there were at times more mundane political forces at work, such as tussles over States' rights and Federal power, or interstate rivalry.

Although our two case studies reveal significant similarities, with both the Australian honours system and the Australian of the Year award experiencing periods of controversy during and immediately after the period of the Whitlam Government, there were also some clear differences. The weight of tradition seems to have been particularly onerous for the honours system, which even in its new Australian form was based closely on the British model. It had a dignified symbolism as a legacy of Britishness, which shaped debates surrounding its development. By contrast the Australian of the Year award was a new expression of civic nationalism, which was unencumbered by any significant attachment to past practice and, at least in its early phase, bore little symbolic weight. This key difference likely explains why the Australian of the Year award emerged more easily from its period of controversy, while the Order of Australia had a more uncertain path to general acceptance. Nevertheless, after the difficult decades of the 1970s and 1980s, both awards seemed to have reached a broad stability. Arguments remained, but these tended to be more often over issues of selection the representation of sporting heroes, or gender equity, for example - rather than about what sort of vision of Australia's post-imperial future they embodied.

This broad stability was disturbed, for the Order of Australia, in 2014. The Abbott Government's reintroduction of knighthoods and damehoods led to a furore of debate, much of it framed in terms of Australia's relationship with Britain, and the contrasting hopes of monarchists and republicans, ignoring other equally possible frames, such as the efficacy of titles as a form of recognition per se. The conferral of an AK upon Prince Philip less than a year later fanned the flames, further reviving these unresolved controversies about honours and the British connection. Paradoxically, critics of the Duke's Australian knighthood contrasted what they perceived as an imperial honour to a national honour in the Australian of the Year award - yet the latter had begun its life under the auspices of a conservative, monarchist organisation, while the AK was a specifically Australian honour. As the controversy made clear - and as periodic debates over changing the flag or becoming a republic also demonstrate - Australia's transition to a post-imperial identity (like that of other former settler dominions) remains both unfinished and contested. 